\title{
First observation on neustonic plastics in waters off NW Spain (spring 2013 and 2014)
}

\author{
Gago Jesus ${ }^{1,{ }^{*}}$, Henry Maryvonne ${ }^{2}$, Galgani Francois ${ }^{3}$ \\ ${ }^{1}$ Instituto Español de Oceanografía (IEO), Subida a Radio Faro, 50-52, 36390 Vigo, Spain \\ ${ }^{2}$ Institut Français de recherche pour l'exploitation de la Mer (IFREMER), LER/PAC, ZI Bregaillon, 83507 \\ La Seyne/mer, France \\ ${ }^{3}$ Institut Français de recherche pour l'exploitation de la Mer (IFREMER), ZI Furiani, 20600 Bastia, \\ France \\ *Corresponding author : Jesus Gago, email address : iesus.gago@vi.ieo.es
}

\begin{abstract}
:
This paper examines the presence and distribution of plastic particles in waters off the NW Spanish Atlantic coast. A pilot sampling program was initiated in 2013 to study the presence of plastic particles in surface waters. A total of 41 neuston samples were collected using a manta trawl fitted with a $333 \mu \mathrm{m}$ mesh (21 samples in 2013 and 20 samples in 2014). Several types of plastic particles were observed in $95 \%$ of the stations. A total of 1463 plastic microparticles $(<5 \mathrm{~mm} ; \mathrm{mps})$ and 208 mesoparticles ( $>5 \mathrm{~mm}$ and $<20 \mathrm{~mm}$; MPS) were counted. Average concentrations recorded were $0.034 \pm 0.032$ and $0.176 \pm$ $0.278 \mathrm{mps} m-2$ and $0.005 \pm 0.005$ and $0.028 \pm 0.043$ MPS m-2, respectively for 2013 and 2014 .

Results on this emerging topic are discussed as a preliminary step towards implementation of the Marine Strategy Framework Directive in the region. Harmonization of protocols for determination of plastic particles is urgently needed in order to compare results between regions and to ensure coherence in the implementation of the MSFD. This aspect is also important at a worldwide scale.
\end{abstract}

\section{Highlights}

Plastic particles (micro and meso) were sampled in surface waters with a Manta trawl. Values are reported for the first time in NW Iberian coast during spring 2013-2014. Plastics concentrations were very variable, spatially and temporally. Microplastics $(<5 \mathrm{~mm})$ constituted $93 \%$ of total plastics by number of items.

Keywords : Marine litter, Floating plastics, Microplastics, European MSFD, NW Spain 


\section{Introduction}

The ubiquity of plastics in the marine environment and biota from across the globe has highlighted the prevalence of this type of pollution within our oceans. Ever since the mid-1990s, the global production of plastics has been accompanied by an accumulation of plastic litter in the marine environment (Derraik, 2002). The massive accumulation of plastics in the marine environment has recently been recognised as a major problem worldwide by scientists, national authorities and other stakeholders (see e.g. Rochman et al., 2013; Eriksen et al., 2014).

Plastic particles can enter the marine environment either directly (e.g. preproduction pellets and/or granules used as abrasives in cleaning products) or indirectly due to fragmentation of larger plastic litter (Andrady et al., 2011). They disintegrate in the environment and are possibly transported as pellets $(<5 \mathrm{~mm})$ and powders $(<1 \mathrm{~mm})$ used to manufacture everyday items (Andrady, 2003). The relative importance of the primary and secondary sources of microplastics in the marine environment is still unknown (Andrady, 2011). Moreover, the rate of formation of secondary microplastics is difficult to predict because there are no systematic studies available of the disintegration processes of plastics under realistic conditions (Arthur et al., 2009; Andrady, 2011).

Plastic particles are not only widely dispersed in the marine environment but are also present in the water column, on beaches and on the seabed (Barnes et al., 2009; Browne et al., 2011; Claessens et al., 2011; Collignon et al., 2012; Colton et al., 1974; Goldstein et al., 2012; Law et al., 2010; Martins and Sobral, 2011). The presence and distribution of plastic debris are strongly influenced by hydrodynamics and show high 
51 spatial variability in the open ocean and in shoreline waters (Barnes et al., 2009;

52 Browne et al., 2010).

53

54

55

56

57

Europe's Marine Strategy Framework Directive (Directive 2008/56/EC, hereafter MSFD) is a key element in Europe for addressing marine litter. Many challenges arise when implementing the MSFD (Borja et al., 2010; Gago et al., 2014) and therefore a study of the impact of plastics in the marine environment becomes quite relevant (Depledge et al., 2013). In a joint effort to implement the monitoring requirements of the MSFD, the IEO (Instituto Español de Oceanografia) and the IFREMER (Institut Français de recherche pour l"exploitation de la Mer) have begun a common monitoring programme for plastics (and specifically microplastics) in surface waters of along the NW Spanish Atlantic coast.

The main goal of this pilot program was to study the distribution of plastics for the first time in surface waters of the NW Spanish Atlantic coast. Two different periods (spring 2013 and 2014) and two size ranges $(<5 \mathrm{~mm}$, microplastics and $>5 \mathrm{~mm}$ and $<20$ $\mathrm{mm}$, mesoplastics) were considered, in order to comply with the MSFD requirements. The study was carried out during a regular fish stock survey conducted in spring (PELACUS). Data on weight of plastic particles were also collected. The present study provides an overview of microplastic pollution (concentration and spatial distribution) in waters off the NW Spanish Atlantic coast. 


\section{Material and methods}

2.1. Study area: An overview of the oceanography of the region

The study area lies in one of the five sub-regions or "marine demarcations" defined by Spain (Bellas, 2014) for implementing the MSFD. General oceanographic data for the area were also studied to verify some of the hypotheses put forward on plastic distribution.

Figure 1 shows mean patterns of surface ocean circulation, river basins, the big coastal cities and bathymetry in the study area. Only names of the three big rivers in the region are shown: Miño, Duero and Adour. The river Duero estuary is located to the south of the study area but waters are transported northwards and therefore affect the study area.

The seasonal large scale climatology interplay between the Azores high pressure cell (strengthened and displaced northward during the summer) and the Icelandic low pressure cell (weakened cell at the time) give rise to winds (northerlies) that favour upwelling off the NW Iberian coast between April and October (Wooster et al., 1976). The oceanographic patterns in the NW Iberian upwelling system reveal a conspicuous succession of mesoscale structures such as jets, meanders, ubiquitous eddies, upwelling filaments and counter-currents, superimposed on the more stable seasonal variations (see e.g. Relvas et al., 2007). The shelf in the Cantabrian Sea (southern Bay of Biscay) is narrow and the hydrography of the region is highly influenced by climatic factors among others. Warm saline waters are transported along the shelf break from autumn to early spring. Changes in wind patterns during spring trigger upwelling of central water and this effect is associated with the appearance of mesoscale structures along the NW Spanish Atlantic coast and in the Cantabrian Sea. Complex dynamics of fronts and 
eddies have been described for the area in spring and summer (Sanchez and Gil, 2000). These large scale climatological patterns in the ecosystem of the region are partly obscured by mesoscale activity. The oceanography of the region is largely dominated by medium sized structures that represent variability of ocean, ,sveatheree (Alvarez-Salgado et al., 2003). For a complete review of the physical oceanography in the region kindly see Relvas et al. (2007).

Based on the described oceanographic scenario, the study area is divided into two different zones. The NW Iberian upwelling system (from the River Miño to Cape Estaca de Bares) and the Cantabrian Sea (from Cape Estaca de Bares to the frontier between Spain and France) as shown in figure 1.

\subsection{Microplastics in the marine environment: the MSFD approach}

The MSFD calls for all the EU's marine regions and sub-regions to reach „Good Environmental Status $^{\text {ee }}$ (GES) by 2020. GES is defined by means of eleven qualitative „descriptors ${ }^{\text {ee }}$. The relevant criteria and indicators applicable to these eleven descriptors are defined in Commission Decision 2010/477/EU. The descriptors are very diverse, closely linked to each other and cover all aspects of marine environmental conservation and protection, including issues ranging from biodiversity to marine noise.

The MSFD"s marine litter descriptor is descriptor 10 ("Properties and quantities of marine litter do not cause harm to the coastal and marine environment") and it is the first time ever that marine litter is addressed comprehensively in a European Directive, to protect the marine environment (see Galgani et al., 2013 for more info on marine litter in the MSFD).

Microparticles of a range of common materials including glass, metal, plastic and paper litter are undoubtedly present in the marine environment. However, the most 
comprehensive data available is for microscopic plastic particles (Hidalgo-Ruz et al., 2012). In the marine environment, the term microplastics was first used in 2004 (Thompson et al., 2004) and is associated with a classification based on size. Microplastics are specifically considered in the MSFD"s descriptor 10 (10.1.3. "Trends in the amount, distribution and, where possible, composition of micro-particles (in particular micro-plastics)"). The attribute will establish baseline quantities, properties and potential impacts of micro-particles, and the hypothesis is that microplastics are likely to be the most significant part of this (Galgani et al., 2014).

There is no general consensus on a specific size nomenclature. Baker et al. (2009) suggested that microplastics be defined as $<5 \mathrm{~mm}$ particles and this approach has been used in our study. Therefore the two sizes studied were: $<5 \mathrm{~mm}$ (microplastics) and $>5$ mm but $<20 \mathrm{~mm}$ (mesoplastics).

\subsection{Sample collection}

Seawater samples for plastic particles are mostly collected using nets (see e.g. Hidalgo- Ruz et al., 2012 for a complete review). The Manta Trawl, a modified neuston net with buoyant wings to keep the net aperture at the sea and air interface, is the most commonly used equipment for sea surface micro-litter analysis based on a reduced volume-methodology (Hidalgo- Ruz et al., 2012).

Forty-five neuston samples were collected in the NW Atlantic and the Cantabrian Sea between March $6^{\text {th }}$ and April $8^{\text {th }}, 2013$ (25 samples), and March $9^{\text {th }}$ and April $8^{\text {th }}, 2014$ (20 samples), during the PELACUS cruise from Spanish waters (R/V "Miguel Oliver"). The samples were collected with a manta trawl net lined with a $333 \mu \mathrm{m}$ mesh (Ryan et al., 2009). The size of the rectangular net opening was $0.6 \times 0.2 \mathrm{~m}^{2}$. The trawl sampled the top $10 \mathrm{~cm}$ of the sea surface, at an average speed of 
1433 knots, over a 20 min interval, for each sample. The trawl was towed from a boom 144 installed on the side of the boat to avoid debris disturbed by the bow wave. The surface 145 area towed was calculated for each tow using the initial and final positions of the ship 146 during the said time period (20 min). Opportunistic sampling was carried out in spring 147 and weather permitting, whenever ship was available.

148 Nets were rinsed to collect all debris stuck to the mesh prior to their transfer into jars. 149 Samples were then reduced to $0.10 \mathrm{~L}$ and fixed in $2.5 \%$ formalin. They were stored in a 150 cool dark place on board the vessel and in the lab prior to analysis. The sampling methodology used was following recommendations of the Technical Subgroup on Marine Litter (TSG ML) which supports the EU Member States in harmonising monitoring protocols and streamlining monitoring strategies within the framework of the MSFD (Galgani et al., 2013). Despite the above, standard methodologies for the analysis of microplastic abundance and distribution are still unavailable (de Lucia et al., 2014; Woodall et al., 2015).

\subsection{Samples analysis}

Samples were placed during $24 \mathrm{~h}$ in graduated $1 \mathrm{~L}$ glass cylinders filled with filtered seawater to separate plastic particles from organic tissue by gravity (see e.g. Collignon et al., 2013), wherein the organic tissue sank to the bottom and the plastic fragments 161 floated at the surface. The supernatant was sieved through a $300 \mu \mathrm{m}$ filter and rinsed thoroughly with distilled water after which particles were transferred to a Petri dish. The organic tissues, made up of mainly plant debris and large planktonic organisms was separated and discarded. The non-organic particles were placed on graph paper and particles $>5 \mathrm{~mm}$ but $<20 \mathrm{~mm}$ were counted and separated. Plastic particles of size 
between 0.3 and $5 \mathrm{~mm}$ were transferred to a Dollfuss tank for counting under a binocular microscope.

After counting particles, the contents of the Petri dishes $(<5 \mathrm{~mm}$ and $>5 \mathrm{~mm})$ were placed in an oven at $50^{\circ} \mathrm{C}$ for 24 hours. They were then transferred to an aluminium cup (tared) using a spatula, weighed (accuracy: $0.1 \mathrm{mg}$ ) and stored in two tubes $(<5 \mathrm{~mm}$ and $>5 \mathrm{~mm})$ prior to subsequent storage for physico-chemical analyses. The presence of microplastics and mesoplastics is expressed as number (or weight) and as sea surface area sampled (particles or weight $\mathrm{m}^{-2}$ ). Plastics debris items are usually subdivided into different size categories; mega-debris $(>100 \mathrm{~mm})$, macro-debris $(>20$ mm diameter), meso-debris (5-20 mm) and micro-debris ( $<5 \mathrm{~mm})$ (Barnes et al., 2009). This study looked at particles with values $<5 \mathrm{~mm}$ (defined as microplastics, $\mathrm{mps}$, lower limit $0.3 \mathrm{~mm}$ ) and those $>5 \mathrm{~mm}$ but $<20 \mathrm{~mm}$ (defined as mesoplastics, MPS) as already mentioned. Bigger items such as bottles, bags, etc collected during sampling were 179 discarded.

\subsection{Precautions to minimise contamination}

Plastic goods are part and parcel of our daily lives (clothes, personal hygiene, pharmaceuticals, bottles, car parts, cups, etc). Precautions were taken to avoid sample contamination when transporting from the field to the laboratory. Only metal and glass equipment was used and material was cleaned prior to sampling and packaging. Samples were stored in glass containers. All containers and sampling equipment were thoroughly cleaned prior to use. In order to minimise sample contamination during sample collection, synthetic clothing and garments likely to shed synthetic fibres (such as fleece) were avoided. Persons involved in sampling were positioned down-wind from the sampling apparatus during deployment and recovery. 

particles. Cotton lab coats were worn to minimise use of synthetic clothing (e.g.

synthetic fleece). During lab work, air circulation in the processing area (windows, doors, etc that could carry air-borne particles) was kept to a minimum and samples were not processed near carpeted areas. Exposure of samples to air was minimum and limited to transfer between containers. Containers were kept covered at all other times.

\section{Results}

Thirty nine out of 41 net tows $(95.1 \%)$ contained plastic debris. No plastic was found in 2 samples (during spring 2013) from the eastern part of the sampling area. During 2014, 3 samples from the Cantabrian Sea were without mesoplastics.

A total of 770 microplastic particles were counted in the 21 samples collected during 2013 which had a total dry weight of $2.93 \mathrm{~g}$. The number of mesoplastics was 113 and they had a total dry weight of $1.72 \mathrm{~g}$. The spring 2014 sample gave a count of 693 microplastic particles in the 20 samples (total dry weight $0.57 \mathrm{~g}$ ) while the number of macroplastic particles counted was 95 (total dry weight $1.35 \mathrm{~g}$ ).

The average concentration of $m p s$ (in number) found was $0.034 \pm 0.032$ and $0.176 \pm 0.028$ $m p s \mathrm{~m}^{-2}$ in 2013 and 2014, respectively. The mean weight of the $m p s$ was $7.5510^{-2} \pm$ $1.1910^{-1}$ and $1.9210^{-2} \pm 2.8410^{-2} \mathrm{mg} \mathrm{m}^{-2}$ during 2013 and 2014, respectively.

Average values (number and weight) for microplastics and mesoplastics normalised to surface $\left(\mathrm{m}^{2}\right)$ with their standard deviation for each oceanographic region (NW Iberian upwelling region and the Cantabrian Sea) are shown in table 1. During spring 2013, lower plastic particles values (in number, $m p s$ and $M P S$ ) are found in both regions as compared to spring 2014 (see table 1). On the other hand the weight of MPS showed a substantial decrease from 2013 to 2014 despite their increased presence and no trend 
was found for weight of the mps particles. The lowest values (no mps in two samples) were found at the northwestern limits of the sampled area and higher values were found near Santander city. However, the distribution during spring 2014 is quite homogenous in the sampled region with the highest values nearest to the Galician rías (city of Vigo in

218 figure 1), with 0.917 and $0.862 \mathrm{mps} \mathrm{m}^{-2}$.

The distribution of mesoplastics was similar to that of microplastics during spring 2013 and 2014 (see figures 2 and 4 for $m p s$ and 3 and 5 for MPS, respectively). The hypothesis is that the mesoscale structures that affect the distribution of phytoplankton and nutrients during the spring bloom in the region (see section 2.1) may also influence the spatial distribution of floating plastic particles.

A strong positive relationship was found between number of mps and MPS particles for all samples collected during 2013 and $2014\left(r^{2}=0.79 ; p<0.001\right)$. On the other hand, no significant relationship was observed for weight of the samples collected.

\section{Discussion}

When comparing abundances of plastic particles from literature, it is important to bear in mind that even though most sampling was done with a neuston net, the mesh size of these nets often differed. Furthermore, despite recommendations for the definition of microplastics as particles smaller than $5 \mathrm{~mm}$ (Arthur et al., 2009; Galgani et al., 2013), many authors still use other size limits such as $1 \mathrm{~mm}$ (Costa et al., 2010; Van Cauwenberghe et al., 2013). Therefore, comparison between studies becomes quite difficult. The results in this study are compared with others that used a similar net size $(\sim 333 \mu \mathrm{m})$ and similar definition of microplastics (particles smaller than $5 \mathrm{~mm}$ ) and mesoplastics ( $>5 \mathrm{~mm}$ but smaller than $20 \mathrm{~mm}$ ). 
A recent microplastics study on the Portuguese coast showed evidence of microplastics in zooplankton samples (Frias et al., 2014). Microplastics were present in $61 \%$ of samples at a depth of $25 \mathrm{~m}$. The different methodologies used for sampling (nets at different depths) means that results cannot be compared directly with this study but what is relevant though is that more particles were found in the upper layer (neustonic layer) due to the floatability of plastics. This also shows that plastic particles are dispersed in the water column due to different processes, which must be taking into account when estimating amount of plastics in the open ocean (see for example Cózar et al., 2014).

The average presence of plastics in our study ( $\sim 95 \%$ of collected samples) tallies with recently published results for the Northeast Atlantic (Lusher et al., 2014) in which the presence was $94 \%$ on average. The result is also quite similar to the frequency in the global ocean estimated recently by Cozar et al. (2014) wherein samples with plastic particles accounted for $88 \%$ in the more than 3000 samples collected from all around the world. The average presence of plastic particles in this study is quite similar to the one found by Eriksen et al. (2013) in the South Pacific subtropical gyre (96\%) and slightly higher than that observed by Collignon and co-workers (2012) (90\%) in the North Western Mediterranean. On the other hand, the results from the present study are substantially higher than those observed by Law et al. (2010) in the North Atlantic and in the Caribbean Sea (from 1986 to 2008); 60\% of net tows contained plastic pieces. Insofar as microplastics are concerned, the highest value during 2013 was found close to the city of Santander, $0.146 \mathrm{mps} \mathrm{m}^{-2}$ (see figure 2) suggesting the importance of the town as an important source and the presence of a convergence zone associated with an intense slope current in this region (Sanchez and Gil, 2000). It is important to note that this accumulation was also observed for seabed litter, with higher densities in this 
area (A. Serrano personal communication). In general, the densities of microplastics found in the NW Iberian waters are comparable to those observed in other areas of the world (Hidalgo-Ruz et al., 2012). The mean presence of microplastics estimated in the present study (average value of $0.034 \pm 0.032$ and $0.176 \pm 0.278 \mathrm{mps} \mathrm{m}^{-2}$ for 2013 and 2014, respectively) is quite similar to the one found by Collignon (2012) in the North

Western Mediterranean $\left(0.116 \mathrm{mps}^{-2}\right)$ but lower than the one found in the North Pacific Gyre (0.334 mps $\mathrm{m}^{-2}$; Moore et al., 2001).

In this sense, the present values are substantially higher than the ones obtained from 20 years of monitoring in the Caribbean Sea $\left(0.001 \mathrm{mps} \mathrm{m}^{-2}\right)$, Gulf of Maine $(0.002 \mathrm{mps}$ $\left.\mathrm{m}^{-2}\right)$ and the North Atlantic gyre $\left(0.020 \mathrm{mps} \mathrm{m}^{-2}\right)$ where the subtropical convergence is 272 responsible for the accumulation of plastic particles (Law et al., 2010). Despite the relevance of the study of Lusher and co-workers (2014), it is not yet possible to directly compare density values due to the lack of intercalibration between the different methods used for sampling (values per area versus volume). The values found on the Spanish coast are quite similar to the ones found on the French coast during the PELGAS cruise in spring 2013, where average values were 0.018 $\pm 0.020 \mathrm{mps}$ (M. Henry unpublished results).

Therefore, the area studied can be considered as one with medium level of microplastic pollution between low-density zones (like the Caribbean or the Gulf of Maine) and regions where plastic particles are concentrated, like the convergence region of the North Pacific. However, the average concentration in the study area is nearly 5 times higher than the one observed in the North Atlantic gyre (Law et al., 2010). This aspect was highlighted recently by Lusher et al. (2014) for a bigger region in the North Atlantic than the one sampled in our study. 
On the subject of mesoplastics, it is important to note that large items were discarded during our sampling. The number of items discarded was not relevant (only a few big items were discarded) but their weight was probably important. The average values (number of particles) for the studied region were $0.004 \pm 0.005$ and $0.028 \pm 0.043$ MPS $\mathrm{m}^{-2}$ for spring 2013 and 2014, respectively (see table 1). The values found in our study are slightly higher that reported by Eriksen et al. (2013) for the South Pacific gyre; 0.002 MPS $\mathrm{m}^{-2}$ using a similar sampling methodology (Manta trawl). Thiel et al (2003) reported data on plastic items for some world areas that were substantially lower

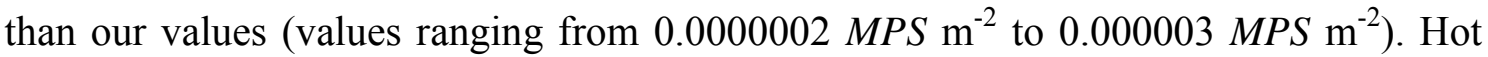
spots in sheltered bays of Indonesia and the Mediterranean Sea with average values of

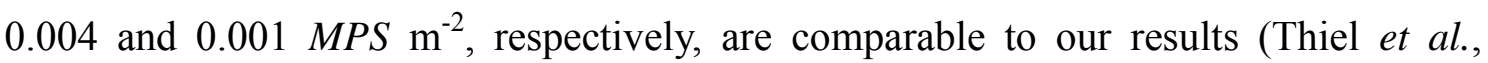
2003). But it must be borne in mind that their data were based on visual surveys (ship based or aerial). Therefore, the estimation of plastic items based on visual observations fails to account for smaller size items of the mesoplastics category.

It is important to note that most particles were smaller than $5 \mathrm{~mm}$ and that the average proportion (number-wise) was similar during both years; $88 \%$ of total plastic particles identified were mps during 2013 and 2014. This result is similar to that found by Lusher and co-workers (2014) for the Northeast Atlantic; $89 \%$ of plastic particles with size $<5 \mathrm{~mm}$. Eriksen and co-workers (2013) in the south Pacific found $98 \%$ of plastic particles with size $<4.75 \mathrm{~mm}$ while Moret-Fergusson et al. (2010) found that $60 \%$ of plastic particles found in the North Atlantic ocean $\left(11-44^{\circ} \mathrm{N}, 55-71^{\circ} \mathrm{W}\right)$ were of size 2-6 mm (more than 18,000 surface net tows since 1991). In this sense, Law et al (2011) and Doyle et al (2011) showed that the most abundant size classes of floating debris in the ocean are the smallest ones. It seems inevitable that even smaller anthropogenic debris including nanoparticles are also present in the marine environment 
311 (Andrady, 2011). However, there is little that can be done at present to monitor particles

312 of this size.

313 The higher presence of floating plastics in our study may possibly be due to the 314 specific configuration and oceanographic characteristics of the study area. Thus, 315 according to Lebreton et al. (2012) and based on the application of the 316 HYCOM/NCODA ocean circulation model coupled with a particle tracking PoL3DD 317 tool, the Bay of Biscay is considered to be a large marine ecosystem where the accumulation of plastic particles on the sea surface is an important oceanographic process. A comparison of data from this study with that from other marine ecosystems supports this hypothesis.

This first set of results also show that the mean weight of the mps particles $\left(7.5510^{-}\right.$ ${ }^{2} \pm 1.1910^{-1}$ and $1.9310^{-2} \pm 2.8410^{-2} \mathrm{mg} \mathrm{m}^{-2} \mathrm{mps}$ during 2013 and 2014, respectively; values per region in table 1) was smaller in this study than those found in the NW Mediterranean (0.202 $\left.\mathrm{mg} \mathrm{m}^{-2} \mathrm{mps}\right)$ by Collignon et al. (2012) but higher than the values found in the North Pacific Gyre (average value; $2.1510^{-6} \mathrm{mg} \mathrm{m}^{-2} \mathrm{mps}$ ) by Eriksen et al. (2014). The weight of microplastics from the present study showed that the load in the Spanish part of the Bay of Biscay (around 54,800 $\mathrm{Km}^{2}$ ) varied from $2067 \mathrm{Kg}$ of $m p s$ in 2013 to 222 in 2014 . The value for the NW Iberian upwelling system $\left(\sim 26,860 \mathrm{Km}^{2}\right)$ was $14 \mathrm{Kg} \mathrm{mps}$ in 2013 and $956 \mathrm{Kg}$ in 2014. It is important to note that the high variability found could be due to the low resolution of the opportunistic sampling.

The good correlation $\left(\mathrm{r}^{2}=0.79\right)$ found between presence of mps and MPS particles 332 (no good correlation observed in weight; $\mathrm{r}^{2}=0.13$ ) points to the hypothesis that plastics of all sizes are concentrated by mesoscale oceanographic physical process in the region as mentioned earlier (section 3). The lack of good correlation with weight may possibly be due to other factors unrelated with abundance (polymer type, biofouling, etc). 
Insofar as monitoring is concerned, the greatest efficiency (not only from an economic but also from a scientific point of view) can be achieved when plastic particles are sampled alongside other routine sampling programmes and may provide relevant and associated data (physical oceanography, plankton abundance, etc). As an example, microparticles on beaches could be sampled while sampling for macro debris on beaches (Hidalgo-Ruz et al., 2012), or in parallel with other routine intertidal monitoring programs (for chemical contaminants, biota, etc). In like manner, sampling the sea surface for plastic particles could also be incorporated into other routine monitoring programmes such as in the present study, which was carried out during the PELACUS cruise. Although temperature and salinity data, etc. were not used in this pilot study on plastic particle distribution, such information could be very relevant for an in-depth study and re-evaluation of sampling design in this region, in order to comply with the MSFD requirements.

Lastly, monitoring programmes carried out within the framework of the MSFD must be able to assess trends and distribution patterns in the marine environment, and also to evaluate the influence of potential measures aimed at reducing concentrations of plastic particles. The results from this study indicate that higher spatial and (probably) temporal resolution is needed in the region to evaluate potential effects of plastic pollution countermeasures.

\section{Conclusions}

The present study provides a first insight into plastic pollution in the Cantabrian

357 Sea and in the NW Spanish Atlantic coastal waters. It provides information on 358 concentration and spatial distribution of plastic particles in the area in spring 20132014. Therefore this data for the NW Spanish Atlantic coast could be used as reference or baseline data to test the effectiveness of any reduction measures adopted in 2016 to 
address the MSFD requirements. The concentration of plastic particles was lower in the

362 NW Iberian upwelling system during spring 2013 as compared to that in the Cantabrian Sea. This could probably be due to wind driven upwelling which results in an important offshore transport of surface coastal waters and their replacement by deeper waters that probably have very low concentrations of plastic particles. On the other hand during spring 2014 no clear geographical trend was observed for plastics particles (mps and $M P S)$ and their distribution was quite homogenous. A literature review indicates that the surface oceanic circulation in the study area is largely governed by mesoscale activity, wherein eddies and other mesoscale process probably underlie the dispersion of floating plastic particles. Additional studies are needed to perform an in-depth analysis of the distribution of plastic particles in surface waters and to assess their origin and fate in the area. Other aspects such as nanoparticles, nature of plastic particles and wind effects on distribution, will likewise have to be taken into account in future studies. the marine environment but also to identify the causes of changes and to guide the process for corrective measures in order to restore Good Environmental Status. It must be borne in mind that the monitoring approaches (especially in emerging issues like microplastics) are still being developed and therefore monitoring implementation and improvement will require ongoing collaborative efforts. On the subject of studying plastic particles, both the sampling methods (device, mesh size and depth layer(s)) and 381 the measurement units used in several studies, point to the need for scientific conventions and standardisations for sampling and quantification of pelagic plastic particles. A standard methodology needs to be developed and agreed upon before initiating monitoring and mitigation activities to support the EU MSFD requirements. 
This work also supplements the role of routine fish stock surveys performed by national authorities and could be a useful tool for the assessment of microplastics in the marine environment, at no additional cost. Therefore, regional cooperation is crucial for implementation of the MSFD as explicitly mentioned in Article 6 of the MSFD.

389 Similarly joint exercises with neighbouring countries in other EU regions would help 390 towards coherence and consistency when applying the MSFD requirements.

391 International cooperation in this field, and not just in the EU countries, would greatly contribute to reducing uncertainties derived from different methodologies and

393 approaches.

This work was sponsored by the IEO and IFREMER. We are very grateful to Rossana Sussarellu, Agueda Cabrero and Gerardo Casas for their help with the sampling. Our sincere gratitude to Pablo Carrera and Isabel Riveiro (chief scientist 2013 and 2014, respectively) and to all crew members of the vessel "Miquel Oliver" for their support at sea. We are also very grateful to Gonzalo Gonzalez-Nuevo for his help with figures. A special thank you to the three unknown reviewers for their valuable comments and suggestions. 


\section{References}

Álvarez-Salgado, X.A., Figueiras, F.G., Pérez, F.F., Groom, S. and others 2003. The Portugal coastal counter current off NW Spain: new insights on its biogeochemical variability. Prog. Oceanogr. 56, 281-321.

Andrady, A.L., 2003. Plastics and the environment. In: Anthony L. Andrady (Ed.), Publisher: John Wiley and Sons, ISBN 0-471-09520-6

Andrady, A.L., 2011. Microplastics in the marine environment. Mar. Pollut. Bull. 62, 15961605.

Arthur, C., Baker, J., Bamford, H., 2009. Proceedings of the international research workshop on the occurrence, effects and fate of microplastic marine debris. NOAA Technical Memorandum NOS-OR\&R30. Silver Spring, $530 \mathrm{pp}$.

Barnes, D. K. A., Galgani, F., Thompson, R. C., Barlaz, M., 2009. Accumulation and fragmentation of plastic debris in global environments. Philos. T. Roy. Soc. B 364, 1985-1998. doi:10.1098/rstb.2008.0205

Bellas, J., 2014. The implementation of the Marine Strategy Framework Directive: Shortcomings and limitations from the Spanish point of view. Mar. Pol. 50, 10-17.

Borja, A., Galparsoro, I., Irigoien, X., Iriondo, A., Menchaca, I., Muxika, I., Pascual, M., Quincoces, I., Revilla, M., Germán, J., Santurtún, M., Solaun, O., Uriarte, A., Valencia, V., Izaskun, I. Implementation of the European Marine Strategy Framework Directive: A methodological approach for the assessment of environmental status, from the Basque Country (Bay of Biscay). Mar. Pollut. Bull. 62(5), 2011, 889-904. ,http://dx.doi.org/10.1016/j.marpolbul.2011.03.031.

Browne, M.A., Galloway, T.S., Thompson, R.C., 2010. Spatial patterns of plastic debris along Estuarine shorelines. Environ. Sci. Technol. 44, 3404-3409.

Browne, M. A., Crump, P., Niven, S. J., Teuten, E., Tonkin, A., Galloway, T., Thompson, R., 2011. Accumulation of Microplastic on Shorelines Worldwide: Sources and Sinks. Environ. Sci. Technol. 45, 9175-9179.

Claessens, M., Meester, S.D., Landuyt, L.V., Clerck, K.D., Janssen, C.R., 2011. Occurrence and distribution of microplastics in marine sediments along the Belgian coast. Mar. Pollut. Bull. 62, 2199-2204.

Collignon, A., Hecq, J. H., Galgani, F., Voisin, P., Collard, F., Goffart, A., 2012. Neustonic microplastic and zooplankton in the North Western Mediterranean Sea. Mar. Pollut. Bull. 64, 861-864.

Colton, J. B., Knapp, F. D., Burns, B. R., 1974. Plastic particles in surface waters of the Northwestern Atlantic. Science 185, 491-497.

Costa, M.F., Ivar do Sul, J.A., Santos-Cavalcanti, J.S., Araújo, M.C.B., Spengler, A.,Tourinho, T.S., 2010. Small and microplastics on the strandline: snapshot of a Brazilian beach. Environ. Monit. Asses. 168, 299-304.

Cózar A., Echevarría, F., González-Gordillo, I., Irigoien, X., Úbeda, B., Hernández-León, S., Palma, A.T., Navarro, S., García-de-Lomas, J., Ruiz, A., Fernández-de-Puelles, M., Duarte, C.M., 2014. Plastic debris in the open ocean. P. Natl. Acad. Sci. USA, 111 (28), 10239-10244. doi: 10.1073/pnas.1314705111.

de Lucia, G.A., Caliani, I., Marra, S., Camedda, A., Coppa, S., Alcaro, L., et al. 2014 Amount and distribution of neustonic micro-plastic off the western Sardinian coast (CentralWestern Mediterranean Sea). Mar. Environ. Res. (100) 10-16. doi: 10.1016/j.marenvres.2014.03.017.

Derraik, J.G.B., 2002. The pollution of the marine environment by plastic debris: a review. Mar. Pollut. Bull. 44, 842-852.

Depledge, M.H., Galgani, F., Panti, C., Caliani, I., Casini, S., Fossi, M.C., 2013. Plastic litter in the sea. Mar. Environ. Res. 92, 279-281. http://dx.doi.org/10.1016/j.marenvres.2013.10.002.

Doyle, M.J., Watson, W., Bowlin, N.M., Sheavly, S.B., 2011. Plastic particles in coastal pelagic ecosystems of the Northeast Pacific Ocean. Mar. Environ. Res. 71, 41-52.

Eriksen, M., Lebreton, L.C.M., Carson, H.S., Thiel, M., Moore, C.J., Borerro, J.C., Galgani, F., Ryan, P.G., Reisser, J. 2014. Plastic Pollution in the World's Oceans: More than 5 
Trillion Plastic Pieces Weighing over 250,000 Tons Afloat at Sea. PLoS ONE 9(12): e111913. doi:10.1371/ journal.pone.0111913

Eriksen, M., Maximenko, N., Thiel, M., Cumminsa, A., Lattin, G., Wilson, S., Hafner, J., Zellers, A., Rifman, S., 2013. Plastic pollution in the South Pacific subtropical gyre. Mar. Pollut. Bull. 68, 71-76.

Frias, P.G.L., Otero, V., Sobral, P., 2014. Evidence of microplastics in samples of zooplankton from Portuguese coastal waters, Mar. Environ. Res. 95, 89-95. http://dx.doi.org/10.1016/j.marenvres.2014.01.001.

Gago, J.,Viñas, L., Besada, V., Bellas, J.. 2014. The link between descriptors 8 and 9 of the Marine Strategy Framework Directive: lessons learnt in Spain. Environ. Sci. Pollut. R. 1-8. DOI: $10.1007 / \mathrm{s} 11356-014-3283-\mathrm{z}$.

Galgani, F., Hanke, G., Werner, S., De Vrees, L. 2013. Marine litter within the European marine Strategy Framework Directive. ICES J. Mar. Sci. 70 (6), 1055-1064. Doi:10.1093/icesJMS/fst122.

Galgani, F., Hanke, G., Werner, S., Oosterbaan, L., Nilsson, P., Fleet, D., Kinsey, S., Thompson, R.C., van Franeker, J., Vlachogianni, T., Scoullos, M., Veiga, J.M., Palatinus, A., Matiddi, M., Maes, T., Korpinen, S., Budziak, A., Leslie, H., Gago, J., Liebezeit, G., 2014. Guidance on Monitoring of Marine Litter in European Seas. Publisher: Publications Office of the European Union, Editor: Hanke G, Werner S, Galgani F, Veiga JM, Ferreira M., ISBN: 978-92-79-32709-4 . DOI:10.2788/99475.

Goldstein, M., Rosenberg, M., Cheng, L., 2012. Increased oceanic microplastic debris enhances oviposition in an endemic pelagic insect. Biol. Let. 8(5), 817-820 doi:10.1098/rsbl.2012.0298.

Hidalgo-Ruz, V., Gutow, L., Thompson, R. C., Thiel, M., 2012. Microplastics in the Marine Environment: A Review of the Methods Used for Identification and Quantification. Environ. Sci. Technol. 46, 3060-3075.

Law, K. L., Moret-Ferguson, S., Maximenko, N. A., Proskurowski, G., Peacock, E. E., Hafner, J., Reddy, C. M., 2010. Plastic Accumulation in the North Atlantic Subtropical Gyre. Science 329, 1185-1188.

Lebreton, L., Greer, S.D., Borrero, J.C., 2012. Numerical modelling of floating debris in the world's oceans. Mar. Pollut. Bull. 64, 653-661. http://dx.doi.org/10.1016/j.marpolbul.2011.10.027

Lusher, A.L., Burke, A., O'Connor, I., Officer R., 2014. Microplastic pollution in the Northeast Atlantic Ocean: Validated and opportunistic sampling, Mar Pollut. Bull. .88, (1-2) 325333. http://dx.doi.org/10.1016/j.marpolbul.2014.08.023.

Martins, J., Sobral, P., 2011. Plastic marine debris on the Portuguese coastline: a matter of size?, Mar. Pollut. Bull. 62, 1649-1653. http://dx.doi.org/10.1016/j.marpolbul.2011.09.028

Moore, C.J., Moore, S.L., Leecaster, M.K., Weisberg, S.B., 2001. A comparison of plastic and plankton in the North Pacific central gyre. Mar. Pollut. Bull. 42, 1297-1300.

Morét-Ferguson, S., Law, K.L., Proskurowski, G., Murphy, E.K., Peacock, E.E., Reddy, C.M., 2010. The size, mass, and composition of plastic debris in the western North Atlantic Ocean. Mar. Pollut. Bull. 60(10), 1873-1878. doi:10.1016/j.marpolbul.2010.07.020

Relvas, P., Barton, E.D., Dubert, J., Oliveira, P.B., Peliz, A., da Silva, J.C.B., Santos., A.M.P., 2007. Physical oceanography of the western Iberia ecosystem: Latest views and challenges. Prog. Oceanogr., 74: 149-173.

Rochman, C.M., Browne, M.A., Halpern, B.S., Hentschel, B.T., Hoh, E., Karapanagioti, H., Rios-Mendoza, L., Takada, H., The, S., Thompson, R.C., 2013 . Policy: Classify plastic waste as hazardous. Nature 494, 7436, 169-171.

Ryan, P. G., Moore, C. J., van Franeker, J. A., Moloney, C. L., 2009. Monitoring the abundance of plastic debris in the marine environment. Philos. Trans. R. Soc. London B Biol Sci 364(1526), 1999-2012.

Sánchez, F., Gil., J., 2000. Hydrographic mesoscale structures and Poleward Current as a determinant of hake (Merluccius merluccius) recruiment in southern Bay of Biscay. ICES J. Mar. Sci. 57, 152-170. 
Teuten, E. L., Rowland, S. J., Galloway, T. S., Thompson, R. C., 2007. Potential for plastics to transport hydrophobic contaminants. Environ. Sci. Technol. 41, 7759-7764. McGonigle, D., Russell, A. E., 2004. Lost at sea: Where is all the plastic? Science 304, 838 .

Van Cauwenberghe, L., Vanreusel, A., Mees, J., Janssen, C.R., 2013. Microplastic pollution in deep-sea sediments. Environ. Pollut. 182, 495-499.

Woodall, L.C., Gwinnett, C., Packer, M., Thompson, R.C., Robinson, L.F., Gordon, L.J., 2015 Using a forensic science approach to minimize environmental contamination and to identify microfibres in marine sediments. Mar. Poll. Bull. 95 (1) 40-46., http://dx.doi.org/10.1016/j.marpolbul.2015.04.044.

Wooster, W., Bakun, A., McLain, D.R., 1976. The seasonal upwelling cycle along the eastern boundary of the North Atlantic. J. Mar. Res. 34, 132-141. 
Table 1. Mean values of microplastics (mps) and mesoplastics (MPS) with standard deviation

\begin{tabular}{|c|c|c|c|c|c|}
\hline & Year & \multicolumn{2}{|c|}{2013} & \multicolumn{2}{|c|}{2014} \\
\hline & Region & particles $/ \mathrm{m}^{2}$ & $\mathrm{mg} / \mathrm{m}^{2}$ & particles $/ \mathrm{m}^{2}$ & $\mathrm{mg} / \mathrm{m}^{2}$ \\
\hline \multirow[b]{2}{*}{$\begin{array}{l}\text { microplastics } \\
\text { (mps) } \\
\varnothing<5 \mathrm{~mm}\end{array}$} & $\begin{array}{l}\text { NW Iberian } \\
\text { upwelling system }\end{array}$ & $0.011 \pm 0.016$ & $\begin{array}{l}4.74 \cdot 10^{-} \\
{ }^{4} \pm 8.20 \cdot 10^{-4}\end{array}$ & $0.285 \pm 0.359$ & $\begin{array}{l}3.33 \cdot 10^{-} \\
2 \pm 3.75 \cdot 10^{-2}\end{array}$ \\
\hline & Cantabrian Sea & $0.035 \pm 0.031$ & $\begin{array}{l}7.21 \cdot 10^{-} \\
{ }^{2} \pm 1.17 \cdot 10^{-1}\end{array}$ & $0.086 \pm 0.154$ & $\begin{array}{l}7.73 \cdot 10^{-} \\
{ }^{3} \pm 9.42 \cdot 10^{-3}\end{array}$ \\
\hline mesoplastics & $\begin{array}{l}\text { NW Iberian } \\
\text { upwelling system }\end{array}$ & $0.001 \pm 0.003$ & $\begin{array}{l}1.15 \cdot 10^{-} \\
{ }^{2} \pm 1.80 \cdot 10^{-2}\end{array}$ & $0.055 \pm 0.054$ & $\begin{array}{l}9.47 \cdot 10^{-} \\
{ }^{2} \pm 8.50 \cdot 10^{-2}\end{array}$ \\
\hline $\begin{array}{l}5 \mathrm{~mm}>\varnothing<20 \\
\mathrm{~mm}\end{array}$ & Cantabrian Sea & $0.005 \pm 0.005$ & $\begin{array}{l}3.30 \cdot 10^{-} \\
{ }^{2} \pm 3.09 \cdot 10^{-2}\end{array}$ & $0.007 \pm 0.006$ & $\begin{array}{l}7.54 \cdot 10^{-} \\
{ }^{3} \pm 8.13 \cdot 10^{-3}\end{array}$ \\
\hline
\end{tabular}


529 Figure 1. Map showing the study area and the main hydrographic features. The arrows 530 indicate surface predominant currents during spring with the slope current dominating

531 the study area. Other relevant coastal phenomena (upwelling and plumes) are shown as 532 shadowed areas.

533 Figure 2. Microplastics ( $m p s$ ) during spring 2013 (particles/hectare).

534 Figure 3. Mesoplastics (MPS) during spring 2013 (particles/hectare).

535 Figure 4. Microplastics ( $m p s$ ) during spring 2014 (particles/hectare).

536 Figure 5. Mesoplastics (MPS) during spring 2014 (particles/hectare). 
Highlights (for review)

\section{Research highlights}

-The quantity of plastics in surface waters sampled with a Manta trawl are reported for the first time in NW Iberian coast during spring 2013 and 2014.

-Plastics concentrations were very variable in the NW Spain Atlantic coast with not clear trend, temporally or geographically, observed.

-Microplastics $(<5 \mathrm{~mm}$ ) constituted $93 \%$ of total plastics by number of items. 


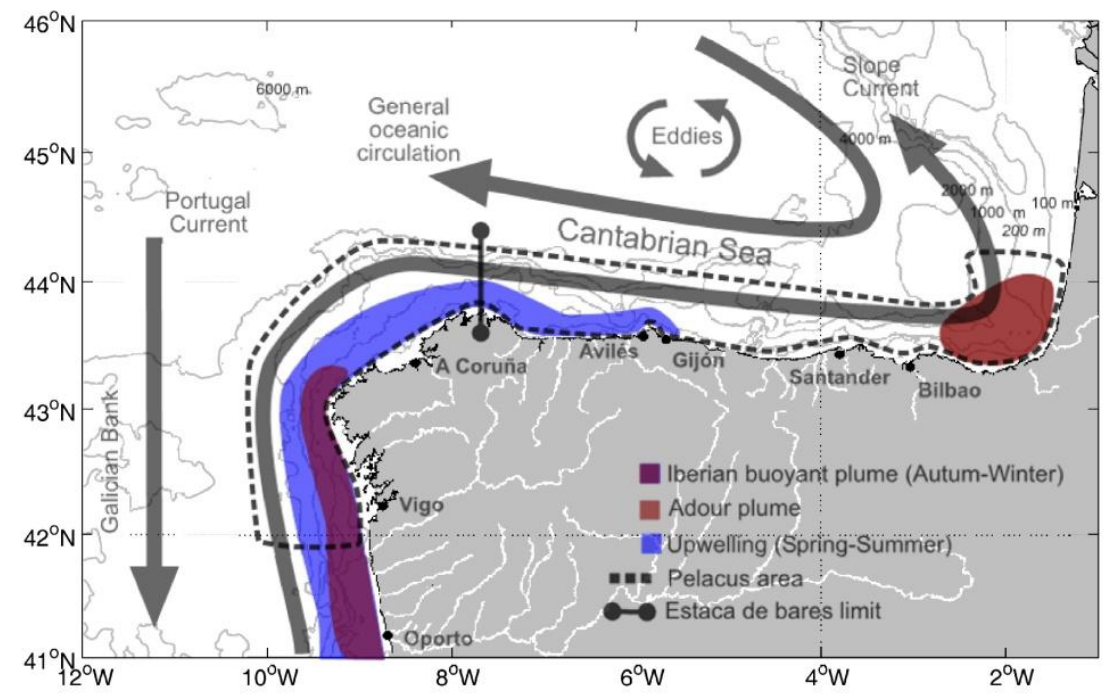

Figure 1 

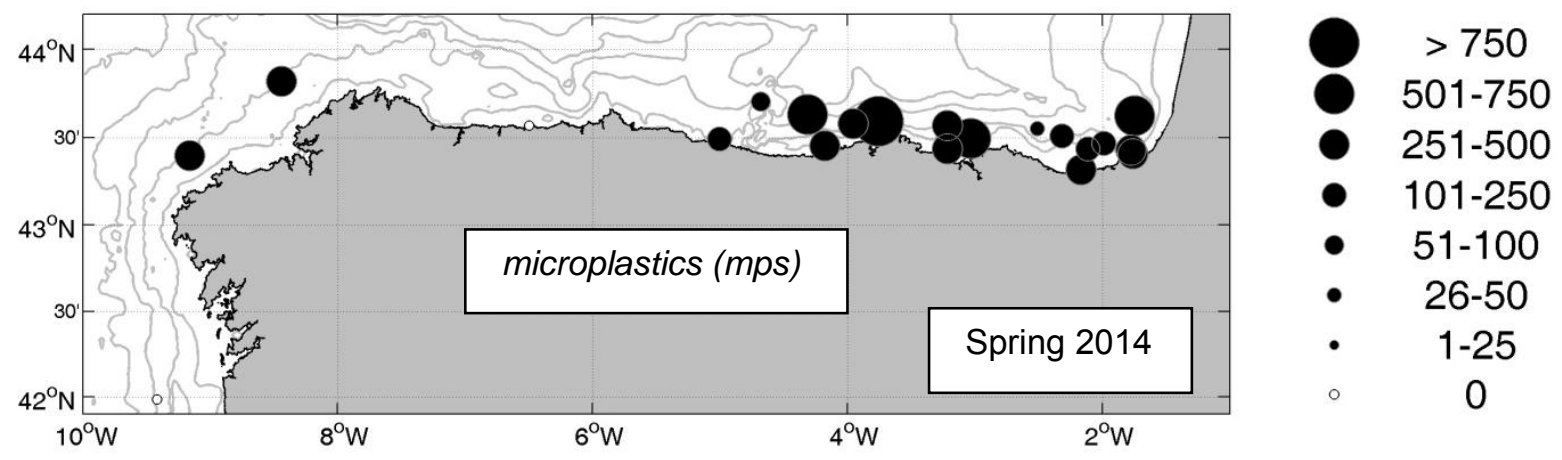

Figure 2 

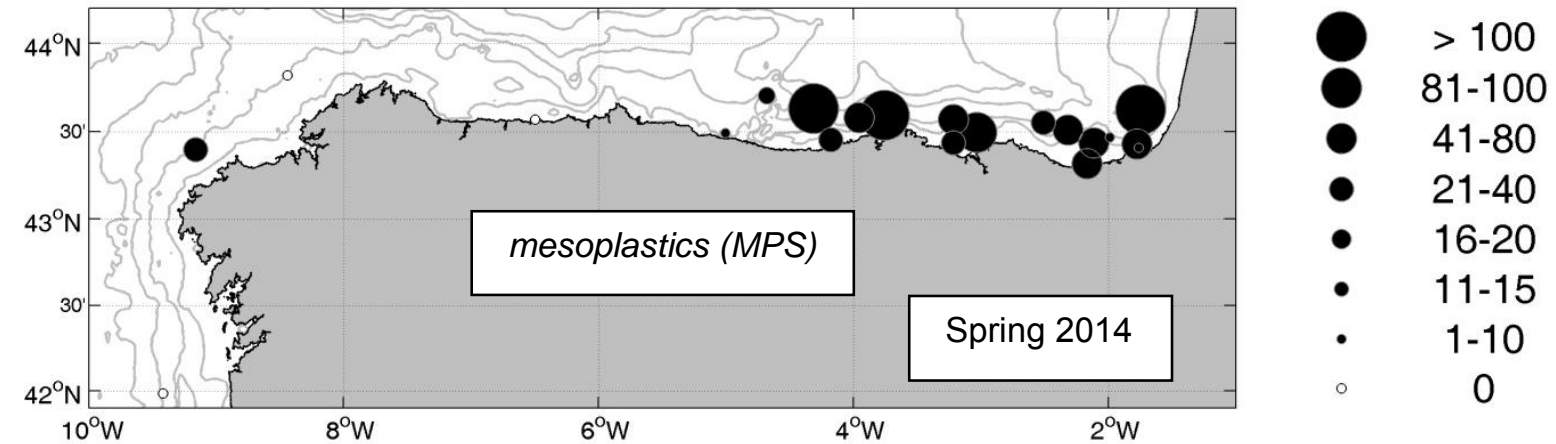

Figure 3 

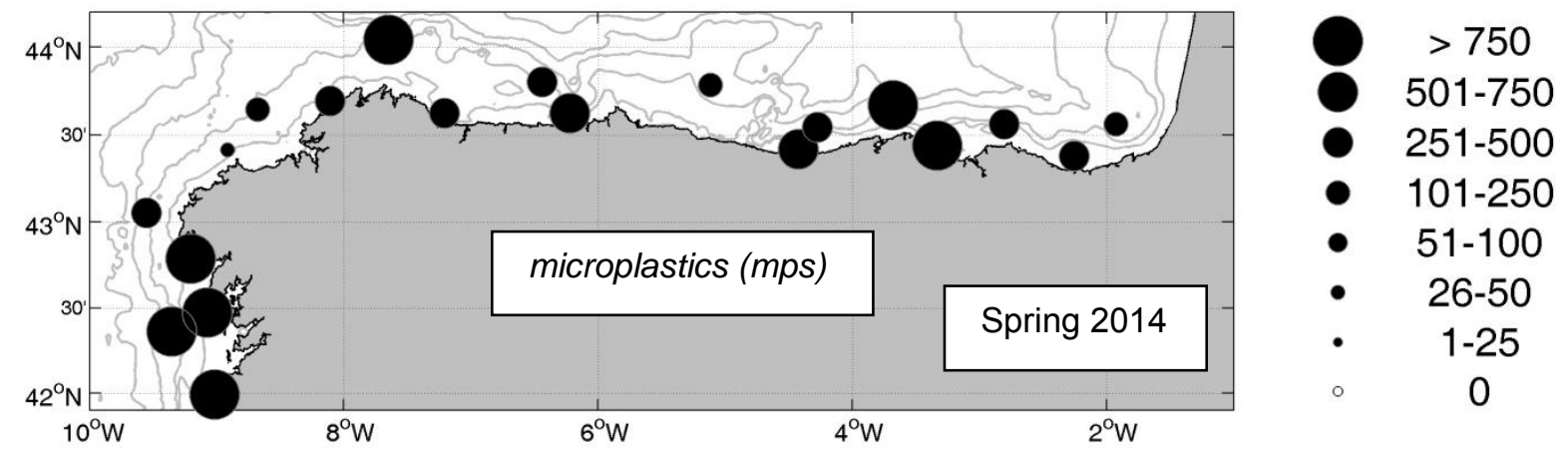

Figure 4 


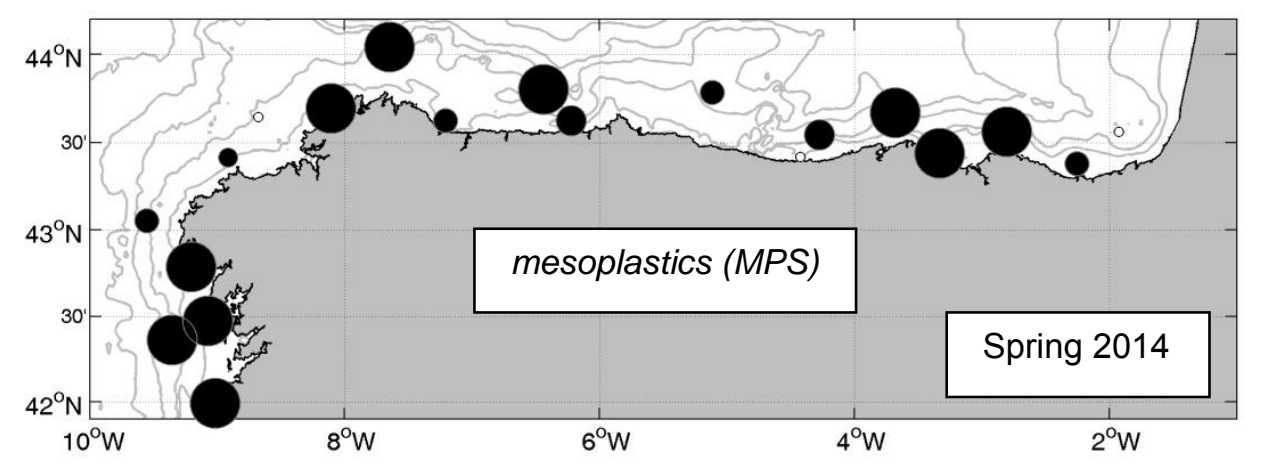

\begin{tabular}{cc}
$>$ & $>100$ \\
\hline & $81-100$ \\
\hline & $41-80$ \\
- & $21-40$ \\
- & $16-20$ \\
- & $11-15$ \\
\hline & $1-10$ \\
\hline
\end{tabular}

Figure 5 
KML File (for GoogleMaps)
Click here to download KML File (for GoogleMaps): figure2.kml

KML File (for GoogleMaps)
Click here to download KML File (for GoogleMaps): figure2.kml

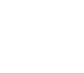

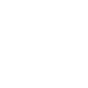

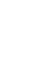

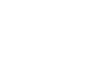

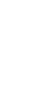

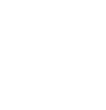

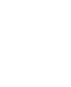

(2)

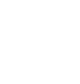

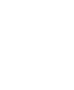

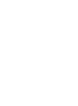

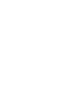

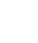

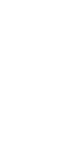


KML File (for GoogleMaps)
Click here to download KML File (for GoogleMaps): figure3.kml

KML File (for GoogleMaps)
Click here to download KML File (for GoogleMaps): figure3.kml

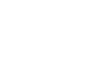

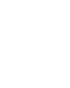

(2)

(2)

(1)

(2)

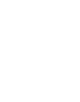

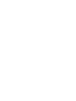

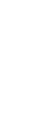

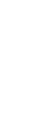
. .

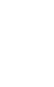

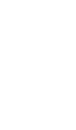


KML File (for GoogleMaps)
Click here to download KML File (for GoogleMaps): figure4.kml

KML File (for GoogleMaps)
Click here to download KML File (for GoogleMaps): figure4.kml

I

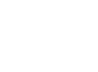

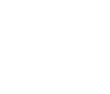

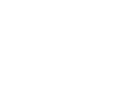

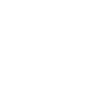

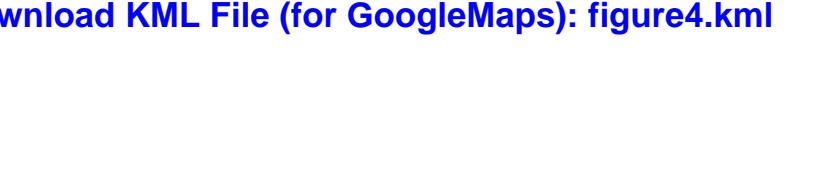

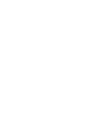

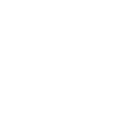
. . .

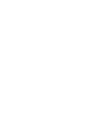
.

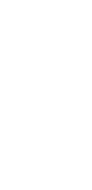

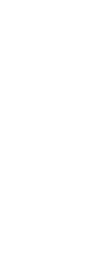

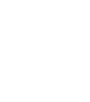

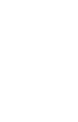

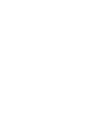

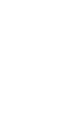

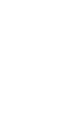

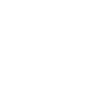


KML File (for GoogleMaps)
Click here to download KML

Click here to download KML File (for GoogleMaps): figure5.kml

Click here to download KML File (tor GoogleMaps): figure $5 . \mathrm{kml}$

File (for GoogleMaps): figure5.kml

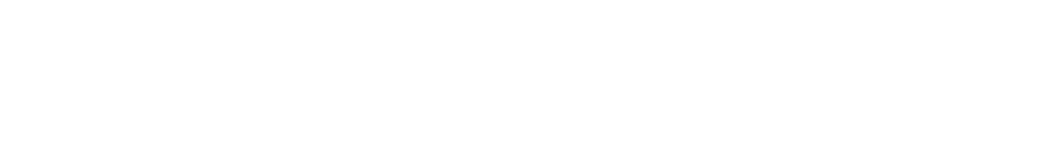

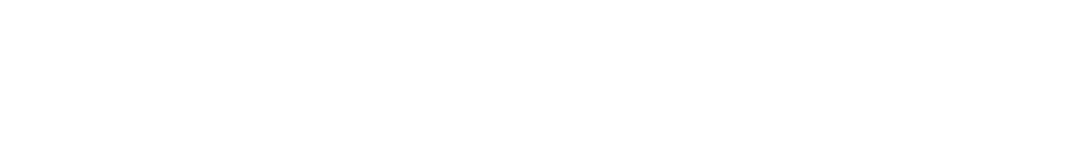

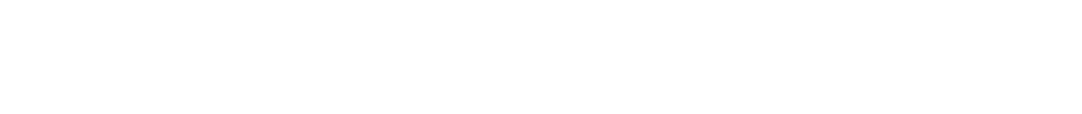
(1) (1) (1) (1) (1) (1) . . . .

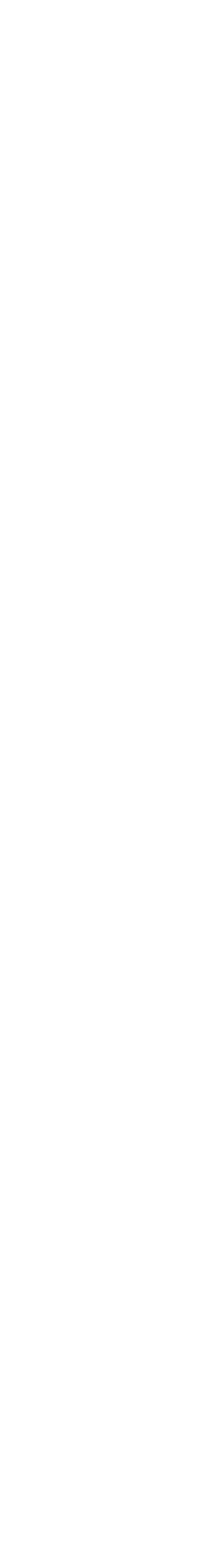

(1) 